\title{
BIOSORPSI LOGAM BERAT Cu(II) MENGGUNAKAN LIMBAH SACCHAROMYCES CEREVISIAE
}

\author{
Adhi Setiawan $\left.{ }^{1, *}\right)$, Fariz Basyiruddin ${ }^{1}$, Denny Dermawan ${ }^{1}$ \\ 1)Program Studi Teknik Pengolahan Limbah, Jurusan Teknik Permesinan Kapal, Politeknik \\ Perkapalan Negeri Surabaya, JI. Teknik Kimia, Kampus ITS Sukolilo, Surabaya, \\ Indonesia 60111 \\ e-mail: adhistw23@gmail.com
}

\begin{abstract}
Abstrak
Biosorpsi merupakan salah satu jenis bentuk pengolahan limbah logam berat dengan menggunakan mikroorganisme, seperti bakteri, alga dan ragi (yeast). Penelitian ini menggunakan ragi (yeast) dari industri bir. Proses preparasi biosorben meliputi pengendapkan, pengeringan, dan pengayakan untuk memperoleh ukuran homogen. Biosorben yang terbentuk kemudian dikontakkan dengan larutan $\mathrm{Cu}$ (II) dengan konsentrasi $25 \mathrm{mg} / \mathrm{L}$ dan diteliti pengaruh $\mathrm{pH}(3,4,5)$, waktu kontak $(1,2,3 \mathrm{jam})$ dan berat biosorben $(0,25,0,5,0,75 \mathrm{gr})$ terhadap kemampuan biosorben dalam menurunkan konsentrasi logam $\mathrm{Cu}$. Selanjutnya pada persen removal tertinggi dilakukan regenerasi menggunakan $\mathrm{HNO}_{3}$. Konsentrasi $\mathrm{Cu}$ yang setelah biosorpsi diuji menggunakan spektrofotometer Uv-Vis. Hasil penelitian menunjukkan bahwa pada $\mathrm{pH} 5$, waktu kontak 1 jam dan berat biosorben $0,75 \mathrm{gr}$ memiliki persen removal yang tertinggi yaitu sebesar $55,36 \%$. Biosorben yang telah diregenerasi mengalami penurunan persen removal logam $\mathrm{Cu}(\mathrm{II})$ dari $55,36 \%$ menjadi $48,2 \%$.
\end{abstract}

Kata kunci: biosorpsi; tembaga (II); Saccharomyces cerevisiae; waste water treatment

\begin{abstract}
Biosorption is a type of waste processing that contain heavy metals using microorganisms, such as bacteria, algae and yeast. This research used yeast from the beer industry. The process of biosorbent preparation includes precipitation, drying, and sieving to obtain a homogeneous size. Biosorbent The biosorbent formed is then contacted with solution of $\mathrm{Cu}(\mathrm{II})$ with concentration 25 $\mathrm{mg} / \mathrm{L}$ and studied the effect of $\mathrm{pH}(3,4,5)$, contact time $(1,2,3$ hours) and the weight of biosorbent $(0.25,0.5,0.75 \mathrm{gr})$ on biosorbent ability to reduce concentration of $\mathrm{Cu}$. Furthermore, the highest percent removal is regenerated using $\mathrm{HNO}_{3}$. The $\mathrm{Cu}$ concentration after biosorption was tested using a UV-Vis spectrophotometer. The results showed that at $\mathrm{pH} 5,1$ hour contact time and weight of $0.75 \mathrm{gr}$ biosorbent had the highest percent removal that is $55.36 \%$. The regenerated biosorbent was decreased percent removal of $\mathrm{Cu}(\mathrm{II})$ metals, from $55.36 \%$ to $48.2 \%$.
\end{abstract}

Keywords: biosorption; copper (II); Saccharomyces cerevisiae; pengolahan air limbah

\section{Pendahuluan}

Seiring dengan berkembangnya teknologi, industri-industri yang ada juga mengalami suatu perkembangan. Perkembangan industri memiliki peranan penting bagi kehidupan manusia. Selain itu, perkembangan tersebut juga memiliki dampak negatif. Salah satu dampak yang muncul ialah dihasilkannya limbah dari proses yang ada di industri. Salah satu jenis limbah yang berbahaya adalah limbah yang mengandung logam berat. Hal tersebut dikarenakan limbah yang mengandung logam berat bersifat toksik dan non biodegradable (Naimah et al., 2011). Salah satu jenis logam berat yang memiliki toksisitas tinggi adalah tembaga (Cu).

Logam $\mathrm{Cu}$ merupakan logam yang bersifat esensial karena dibutuhkan dalam jumlah tertentu oleh organisme. Logam tersebut dapat menimbulkan efek toksik dalam kadar tertentu (Maier et al., 2009). Pada konsentrasi $0,01 \mathrm{ppm}$ dapat membunuh fitoplankton dan 
pada konsentrasi 2,5-3 ppm limbah yang mengandung $\mathrm{Cu}$ dapat membunuh ikan (Fitriyah et al., 2013). Oleh karena itu, dibutuhkan suatu teknologi yang dapat mengolah limbah yang mengandung logam berat tersebut.

Beberapa metode konvensional yang digunakan untuk menghilangkan logam berat di dalam air limbah antara lain koagulasiflokulasi, presipitasi, teknologi membran, ion exchange. Metode tersebut relaltif sederhana namun menghasilkan sludge yang beracun sehingga membutuhkan treatment sebelum dibuang ke lingkungan (Setiawan et al., 2018; Wu et al., 2012).

Biosorpsi merupakan salah satu teknologi yang dapat mengolah logam berat dengan menggunakan mikroorganisme baik hidup maupun mati. Teknologi ini memiliki beberapa kelebihan antara lain efisiensi pengikatan logam berat yang tinggi, regeneratif, serta melimpahnya mikroorganisme yang dapat dijadikan biosorben (Kresnawaty et al., 2007).

Pada umumnya sebagian besar mikroorganisme dapat dimanfaatkan sebagai biosorben, salah satunya yaitu Saccharomyces cerevisiae. Mikroorganisme ini banyak digunakan dalam pada proses fermentasi minuman bir dan memiliki persentase material dinding sel sebagai sumber pengikat logam berat yang tinggi (Khoirunnisa et al., 2017). Biomassa yang digunakan pada penelitian ini adalah limbah Saccharomyces cerevisiae yang sudah mati. Hal tersebut dikarenakan tidak ada perbedaan penyerapan yang berarti antara biomassa yang hidup ataupun mati. Biomassa yang sudah mati memiliki kelebihan dalam proses penyerapan logam berat yakni biomassa yang telah mati tidak memerlukan penambahan nutrisi dalam penyerapannya (Elystia et al., 2018).

Beberapa peneliti telah melaporkan penggunaan biomassa sebagai biosorben logam berat. Cheraghi et al. (2015) melaporkan bahwa biji wijen terbukti cukup efektif dalam mengikat logam $\mathrm{Cd}(\mathrm{II})$ dengan menggunakan metode batch. Wu et al. (2012) melakukan penelitian tentang penggunaan Saccharomyces cerevisiae sebagai biosorben logam As (III). Penelitian tersebut mempelajari pengaruh $\mathrm{pH}$, dosis biosorben, waktu kontak, dan suhu terhadap kinerja Saccharomyces cerevisiae dalam meremoval As(III) di dalam air limbah.

Infornasi tentang penggunaan limbah Saccharomyces cerevisiae sebagai biosorben dalam menyerap logam $\mathrm{Cu}$ (II) belum dibahas secara mendalam oleh beberapa peneliti sebelumnya sehingga perlu dilakukan investigasi lebih mendalam tentang mekanisme biosorpsi logam $\mathrm{Cu}(\mathrm{II})$ oleh limbah Saccharomyces cerevisiae. Penelitian ini bertujuan untuk mempelajari pengaruh $\mathrm{pH}$, waktu kontak, berat, dan regenerasi Saccharomyces cerevisiae dalam menyerap logam Cu(II). Selain itu, struktur kimia biosorben sebelum dan setelah mengadsorpsi logam $\mathrm{Cu}(\mathrm{II})$ dianalisis mengunakan Fourier Tranform Infrared (FT-IR).

\section{Metodologi Penelitian}

\section{Persiapan Alat dan Bahan}

Peralatan yang digunakan dalam penelitian antara lain Spektrofotometer Uv-Vis Cary 60, magnetic stirrer Cimarec, timbangan analitik Nimbus, $\mathrm{pH}$ meter, dan oven.

Bahan-bahan yang digunakan antara lain biomassa hasil samping fermentasi bir, $\mathrm{HNO}_{3}$ $1 \mathrm{M}$ (SAP Chemicals), $\mathrm{CuSO}_{4} .5 \mathrm{H}_{2} \mathrm{O}$ (SAP Chemicals), larutan $\mathrm{NH}_{4} \mathrm{OH} \quad 10 \%$ (SAP Chemicals), Na-Dietilditiokarbamat (Merck).

\section{Proses Biosorpsi}

Limbah hasil samping fermentasi bir yang mengandung yeast (Saccharomyces cerevisiae) diendapkan selama 24 jam. Endapan yeast selanjutnya disaring dan dikeringkan dioven pada suhu $80^{\circ} \mathrm{C}$ selama 24 jam. Yeast selanjutnya diayak dengan menggunakan ayakan 80 mesh sehingga diperoleh ukuran yang seragam.

Biosorben yeast selanjutnya dikontakkan dengan larutan $\mathrm{Cu}(\mathrm{II})$ konsentrasi $25 \mathrm{mg} / \mathrm{L}$ dengan volume $100 \mathrm{~mL}$ disertai dengan pengadukan pada kecepatan $250 \mathrm{rpm}$. Variasi massa biosorben yang digunakan pada penelitian ini antara lain 0,25; 0,50; dan 0,75 g. Pengaturan $\mathrm{pH}$ pada proses adsorpsi dilakukan dengan penambahan larutan $\mathrm{HNO}_{3}$ $0,1 \mathrm{M}$ dengan variasi antara lain 3, 4, dan 5 . Proses adsorpsi dilakukan secara batch pada waktu kontak antara lain 1, 2, dan 3 jam. Setelah proses adsorpsi biosorben dipisahkan dengan filtratnya menggunakan kertas saring.

\section{Analisis Konsentrasi Cu(II) Pada Larutan}

Analisis kadar logam $\mathrm{Cu}(\mathrm{II})$ menggunakan metode spektrofotometri (Pratiwi dan Sunarto, 2018). Pembuatan kurva kalibrasi dilakukan dengan menyiapkan beberapa larutan $\mathrm{Cu}$ dengan konsentrasi yang berbeda. Sebanyak 6 buah labu ukur $50 \mathrm{~mL}$ masing-masing diisi larutan $\mathrm{Cu}(\mathrm{II}) 25 \mathrm{mg} / \mathrm{L}$ berturut-turut yaitu tanpa larutan $\mathrm{Cu}, 2,4,6,8$, dan $10 \mathrm{~mL}$. 
Masing-masing larutan tersebut ditambah aquades sebanyak $10 \mathrm{~mL}$. Selanjutnya larutan ditambahkan $5 \mathrm{ml} \mathrm{NH} \mathrm{NOH}_{5} \%+5 \mathrm{~mL}$ Na-dietilditiokarbamat $1 \%$ dan diencerkan dengan aquades hingga tanda batas. Larutan dibiarkan dikocok perlahan dan dibiarkan selama 3 menit untuk mencapai waktu kestabilan kompleks yang maksimum. Pengujian dengan spektrofotometer dilakukan pada penjang gelombang $450 \mathrm{~nm}$. Penentuan kadar $\mathrm{Cu}$ setelah proses adsorpsi dilakukan dengan metode yang sama sebagaimana proses kalibrasi namun pengambilan sampel larutan $\mathrm{Cu}$ setelah proses adsorpsi dilakukan sebanyak $5 \mathrm{~mL}$. Efisiensi removal logam $\mathrm{Cu}(\mathrm{II})$ oleh Saccharomyces cerevisiae dihitung menggunakan persamaan (1) berikut:

$\%$ Removal $\mathrm{Cu}=\frac{\left[\mathrm{Cu}_{\mathrm{2wa}}-[\mathrm{Cu}]_{\mathrm{akhir}}\right.}{\left.\left.{ }_{\mathrm{Cu}}\right]_{\mathrm{zwa}}\right]} \mathrm{x} 100 \%$

Dengan $[\mathrm{Cu}]_{\text {awal }}$ dan $[\mathrm{Cu}]_{\text {akhir }}$ masing-masing merupakan konsenttrasi logam $\mathrm{Cu}$ (II) sebelum dan setelah biosorpsi (mg/L).

\section{Regenerasi Biosorben}

Pengaruh regenerasi biosorben terhadap kinerja adsorpsi logam $\mathrm{Cu}(\mathrm{II})$ dianalisis dengan mengambil salah satu sampel biosorben dengan persen removal $\mathrm{Cu}(\mathrm{II})$ tertinggi. Ferraz et al. (2004) melaporkan bahwa penggunaan larutan asam mineral seperti halnya $\mathrm{HNO}_{3}$ cukup efektif sebagai agen pendesorpsi ion logam karena dapat menurunkan $\mathrm{pH}$ yang dapat menggeser posisi ion logam yang telah menempati situs pengikatan (binding sites). Regenerasi dilakukan dengan cara mengontakkannya dengan $\mathrm{HNO}_{3} \quad 0,1 \quad \mathrm{M}$ sebanyak $100 \mathrm{~mL}$ selama 30 menit dengan menggunakan magnetic stirrer. Biosorben yang telah diregenerasi selanjutnya digunakan kembali sebagai proses adsorpsi logam $\mathrm{Cu}(\mathrm{II})$ pada konsentrasi $25 \mathrm{mg} / \mathrm{L}$.

\section{Analisis Struktur Kimia Biosorben}

Analisis gugus fungsi yang dari Saccharomyces cerevisiae sebelum dan setelah mengikat logam $\mathrm{Cu}(\mathrm{II})$ dianalisis dengan menggunakan Fourier Tranform Infrared (FT-IR) (Thermo Scientific Nicolet iS10) pada panjang gelombang 4000- 400 $\mathrm{cm}^{-1}$.

\section{Hasil dan Pembahasan}

Gambar 1 menunjukkan grafik pengaruh $\mathrm{pH}$ larutan terhadap persen removal $\mathrm{Cu}(\mathrm{II})$. $\mathrm{pH}$ merupakan salah satu faktor utama yang mempengaruhi terjadinya proses biosorpsi. $\mathrm{pH}$ memiliki pengaruh terhadap muatan yang ada pada situs aktif biosorben, spesies dari tembaga dan tingkat ionisasi dari biosorben selama bereaksi. Ketiga grafik tersebut menunjukkan bahwa semakin besar nilai $\mathrm{pH}$ maka persen removal $\mathrm{Cu}(\mathrm{II})$ semakin tinggi. Persen removal $\mathrm{Cu}(\mathrm{II})$ maksimal terjadi pada $\mathrm{pH}$ 5. Hal tersebut disebabkan pada $\mathrm{pH}$ yang lebih rendah dari 3 situs aktif permukaan dinding sel mikroorganisme memiliki muatan yang positif sedangkan pada $\mathrm{pH}$ lebih tinggi dari 3 cenderung bermuatan negatif. Hal tersebut menyebabkan terjadinya interaksi antara situs aktif permukaan dinding sel mikroorganisme yang bermuatan negatif dengan ion $\mathrm{Cu}(\mathrm{II})$ yang bermuatan positif sehingga proses biosorpsi cenderung mengalami peningkatan pada interval $\mathrm{pH} 3-6$ (Peng et al., 2010).

Faktor $\mathrm{pH}$ berpengaruh terhadap spesies ion logam di dalam larutan. Ion logam yang terdapat dalam larutan sebelum mengalami proses adsorpsi oleh adsorben terlebih dahulu mengalami hidorolisis menghasilkan proton dengan mekanisme reaksi kimia pada persamaan (2) berikut:

$\mathrm{M}^{2+}+\mathrm{nH}_{2} \mathrm{O} \rightleftharpoons\left[\mathrm{M}(\mathrm{OH}) \mathrm{n}^{2-n}\right]^{+}+\mathrm{nH}^{+}$

Kompleks hidrokso $\left[\mathrm{M}(\mathrm{OH}) \mathrm{n}^{2-n}\right]^{+}$yang terbentuk akan lebih mudah untuk teradsorpsi bila dibandingkan dengan kation logam bebas $\left(\mathrm{M}^{2+}\right)$. Pada kondisi $\mathrm{pH} 1$ sampai 4 yang memiliki tingkat keasaman lebih tinggi dari $\mathrm{pH}$ 5 persamaan tersebut akan bergeser ke kiri yang menyebabkan jumlah dari kompleks hidrokso logam yang terbentuk lebih sedikit dan jumlah kation logam bebas lebih banyak. Pada $\mathrm{pH} 5$ proses biosorpsi relatif tinggi. Hal tersebut disebabkan kompleks hidrokso logam yang terbentuk lebih banyak dan permukaan dari biosorben akan bermuatan negatif sehingga akan terjadi tarik menarik melalui gaya elektrostatik yang menyebabkan peningkatan adsorpsi (Sembiring et al., 2009). Pada penelitian yang dilakukan oleh Peng et al. (2010) menunjukkan bahwa persen removal logam berat meningkat seiring dengan meningkatnya nilai $\mathrm{pH}$ pada rentang 2 sampai 5.

Gambar 2 menunjukkan grafik hubungan antara waktu kontak dengan persen removal $\mathrm{Cu}(\mathrm{II})$. Waktu kontak merupakan salah satu faktor yang berperan penting dalam proses biosorpsi. Hasil penelitian menunjukkan bahwa semakin lama waktu kontak maka persen removal semakin rendah. Hal tersebut 
disebabkan semakin banyaknya ion $\mathrm{Cu}$ yang terserap ke dalam biosorben Saccharomyces cerevisiae. Penyerapan ion logam tersebut menyebabkan terbentuknya ion yang berjejal pada permukaan biosorben sehingga menurunkan luas permukan biosorben Saccharomyces cerevisiae. Hal tersebut menyebabkan penurunan daya adsorpsi $\mathrm{Cu}$ (II) sehingga mengakibatkan ion logam yang telah terikat pada biosorben cenderung terdesorpsi kembali pada larutan (Irawan et al., 2015).
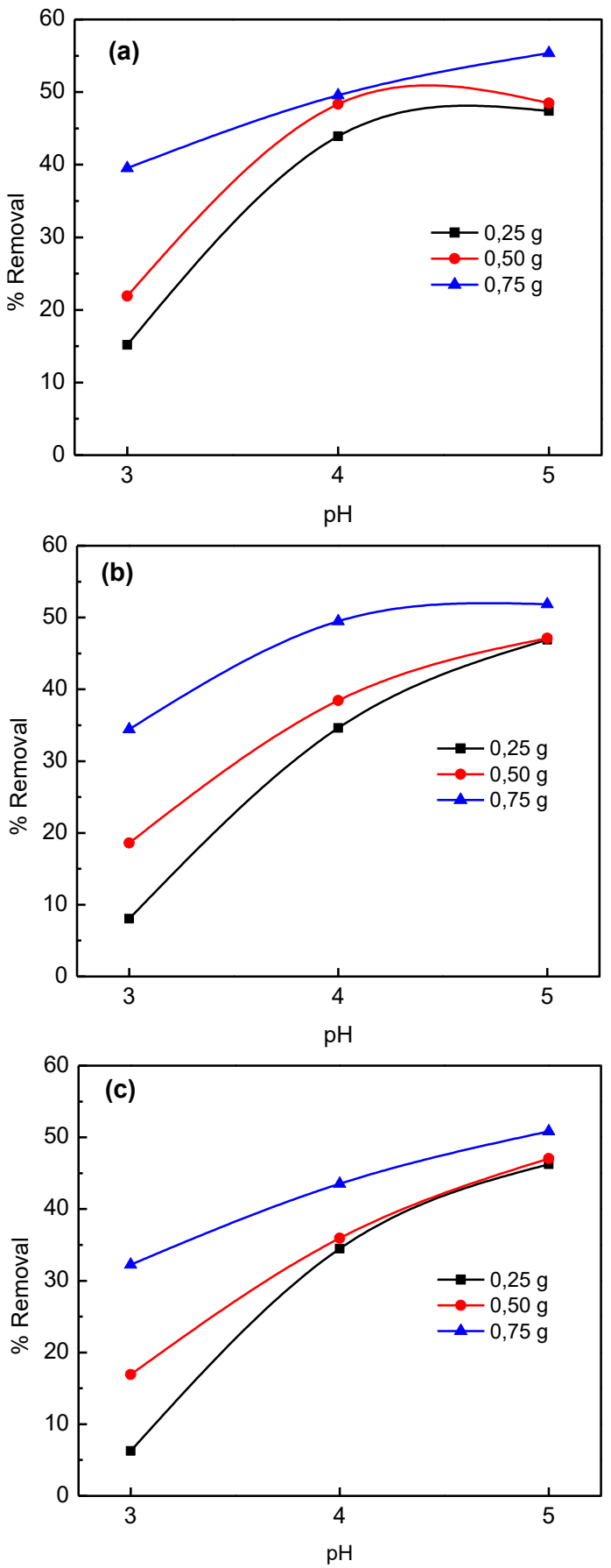

Gambar 1. Biosorpsi logam $\mathrm{Cu}(\mathrm{II})$ pengaruh Ph pada kondisi (a) waktu kontak 1 jam (b) 2 jam (c) 3 jam.
Penelitian yang dilakukan oleh Bhuvaneshwari et al. (2011) menunjukkan bahwa persen removal logam berat oleh biosorben mengalami peningkatan pada waktu kontak 20 menit sampai dengan 90 menit.
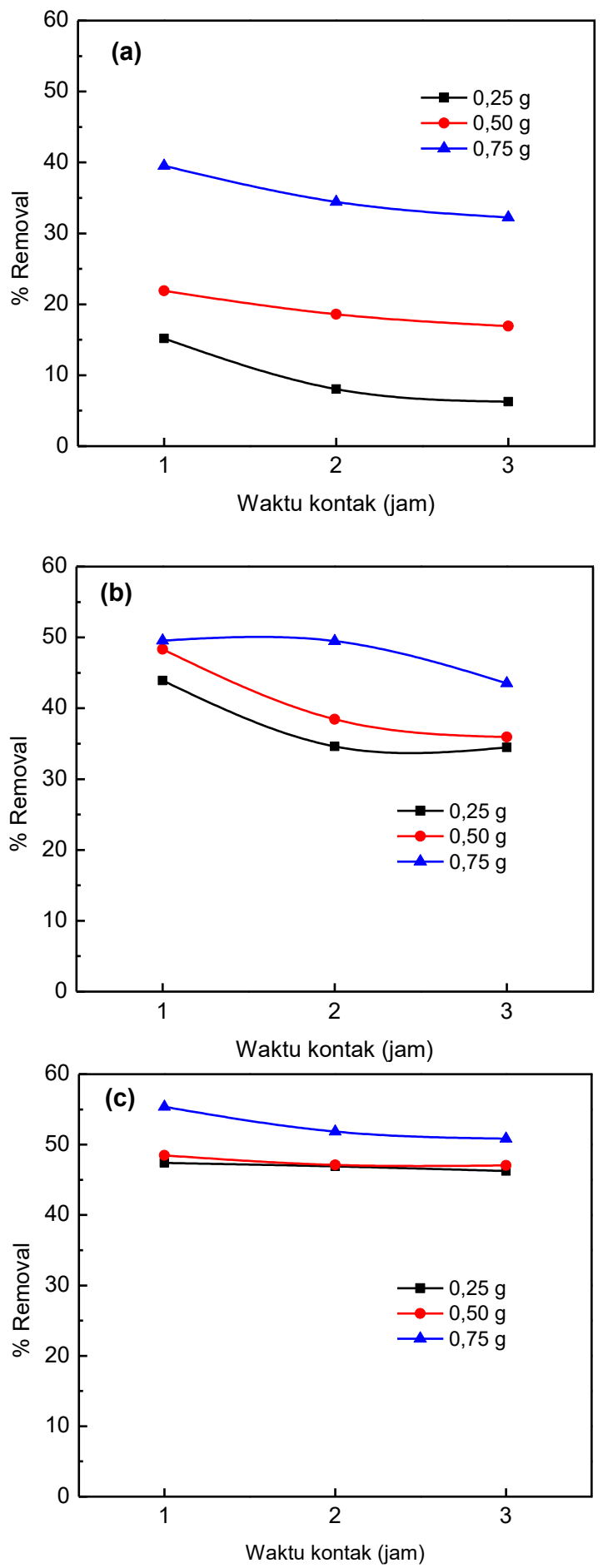

Gambar 2. Biosorpsi logam $\mathrm{Cu}(\mathrm{II})$ pengaruh waktu kontak pada kondisi (a) $\mathrm{pH} 3$ (b) $\mathrm{pH} 4$ (c) $\mathrm{pH} 5$

Persen removal biosorben mengalami penurunan pada waktu 90 menit sampai dengan 240 menit. Menurut Bhuvaneshwari et al. (2011) hal tersebut dikarenakan pada tahap awal adsorpsi gradient konsentrasi 
antara film cairan yang berada di sekitar partikel adsorben dan situs pori yang tersedia besar, karena hal tersebut laju adsorpsi lebih cepat. Pada tahap selanjutnya tingkat adsorpsi menurun disebabkan difusi pori yang terjadi lambat dari ion yang terlarut ke dalam sebagian adsorben.
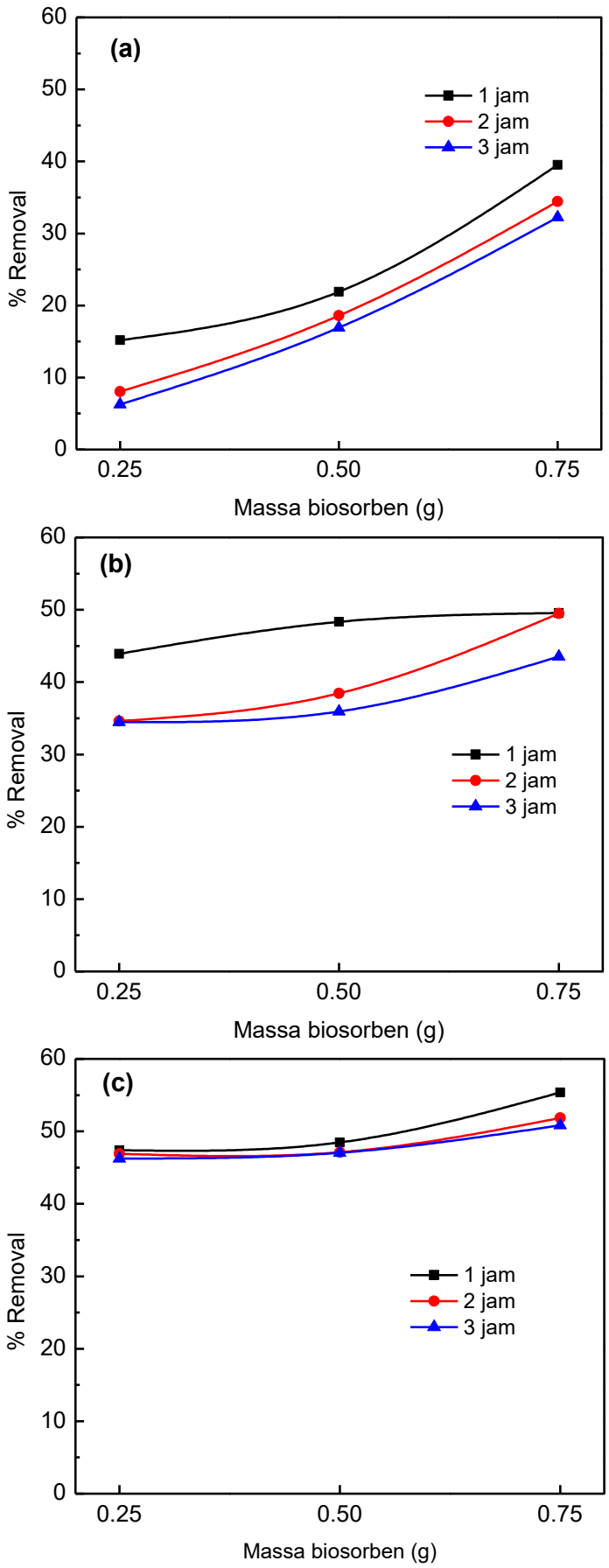

Gambar 3. Biosorpsi logam Cu(II) pengaruh massa biosorben pada kondisi (a) $\mathrm{pH} 3$ (b) $\mathrm{pH}$ 4 (c) $\mathrm{pH} 5$

Gambar 3 menunjukkan grafik pengaruh massa biosorben dengan persen removal. Berat dari biosorben merupakan salah satu faktor penting dalam proses biosorpsi. Hasil penelitian menunjukkan bahwa bahwa peningkatan massa biosorben menyebabkan Peningkatan massa biosorben di dalam larutan menyebabkan meningkatnya jumlah gugus yang aktif penyerap logam berat. Hal tersebut menyebabkan peningkatan persen removal Cu(II) di dalam larutan (Gochev et al., 2014).

Hasil penelitian pada Gambar 1, 2, dan 3 menunjukkan bahwa proses biosorpsi logam $\mathrm{Cu}$ (II) oleh Saccharomyces cerevisiae pada kondisi $\mathrm{pH} 5$, waktu kontak 1 jam, dan berat biosorben $0,75 \mathrm{~g}$ menghasilkan persen removal $\mathrm{Cu}$ (II) maksimum yakni sebesar $55,36 \%$. Hasil penelitian tersebut menunjukkan bahwa limbah Saccharomyces cerevisiae cukup efektif digunakan sebagai biosorben dalam meremoval logam $\mathrm{Cu}$ (II) di dalam air limbah. Selain itu, hasil penelitian yang serupa telah dilaporkan peneliti sebelumnya tentang penggunaan Saccharomyces cerevisiae sebagai biosorben logam berat. Wu et al. (2012) melaporkan bahwa penggunaan biosorben Saccharomyces cerevisiae dapat meremoval As(III) maksimum sebesar $60 \%$ pada kondisi $\mathrm{pH} 5$, dosis $5 \mathrm{~g} / \mathrm{L}$, serta waktu kontak 240 menit. Fadel et al. (2017) menggunakan Saccharomyces cerevisiae sebagai penyerap logam Mn (II) pada air tanah. Hasil penelitian menunjukkan bahwa persen removal maksimum sekitar $90 \%$ terjadi pada kondisi $\mathrm{pH} 7$, dosis $0,1 \mathrm{~g} / \mathrm{L}$, serta waktu 30 menit. Duda-Chodak et al. (2012) pada penelitiannya melaporkan bahwa penggunaan Saccharomyces cerevisiae dapat menurunkan kandungan $\mathrm{Pb}(\mathrm{II})$ sebesar $90 \%$ dengan waktu kontak 20 menit serta pada dosis $1 \mathrm{~g} / \mathrm{L}$.

Tabel 1. menunjukkan hasil pengujian kinerja adsorpsi biosorben Saccharomyces cerevisiae sebelum dan setelah proses regenerasi menggunakan $\mathrm{HNO}_{3} \quad 0,1 \quad \mathrm{M}$. Biosorben yang diregererasi merupakan hasil adsorpsi logam $\mathrm{Cu}$ pada konsisi pH 5, waktu kontak 1 jam, dan berat biosorben $0,75 \mathrm{~g}$.

Tabel 1. Kinerja Biosorben Setelah Proses Regenerasi

\begin{tabular}{ccc}
\hline $\begin{array}{c}\text { Konsentrasi } \\
\text { Awal Cu(II) } \\
(\mathrm{mg} / \mathrm{L})\end{array}$ & \multicolumn{2}{c}{ \% Removal Cu(II) } \\
\cline { 2 - 3 } & $\begin{array}{c}\text { Sebelum } \\
\text { Regenerasi }\end{array}$ & $\begin{array}{c}\text { Setelah } \\
\text { Regenerasi }\end{array}$ \\
\hline 25 & 55,36 & 48,20 \\
\hline
\end{tabular}

Hasil analisis data pada Tabel 1 menunjukkan bahwa persen removal $\mathrm{Cu}(\mathrm{II})$ setelah dilakukan proses regenerasi lebih besar daripada konsentrasi akhir $\mathrm{Cu}$ sebelum diregenerasi. Hal ini menandakan bahwa kemampuan biosorben Saccharomyces 
cerevisiae dalam mengikat logam berat terjadi penurunan. Hal tersebut disebabkan oleh rusaknya struktur dari biosorben. Hal lain yang dapat menyebabkan penurunan kemampuan biosorben dalam mengadsorpsi logam berat adalah penurunan massa biosorben. Penurunan massa yang diperoleh setelah regenerasi Sacharomyces Cerevisiae menggunakan $\mathrm{HNO}_{3} \quad 0,1 \mathrm{M}$ yakni sebesar $0,18 \mathrm{~g}$. Pengurangan berat biosorben disebabkan kondisi biomassa yang mengalami perubahan struktur setelah kontak dengan larutan pendesorpsi yang bersifat asam dan ikut terlarut. Bahkan Saeed et al. (2003) pada penelitiannya melaporkan bahwa penggunaan larutan asam sebagai agen pendesorpsi dilaporkan dapat menyebabkan kerusakan pada struktur biosorben yang menyebabkan penurunan kemampuan biosorben dalam mengadsorpsi logam berat.

Gambar 4 menunjukkan hasil FT-IR biosorben Saccharomyces cerevisiae sebelum dan setelah dikontakkan dengan larutan $\mathrm{Cu}(\mathrm{II})$. Pada sampel biosorben sebelum adsorpsi pada area panjang gelombang $3269,78 \mathrm{~cm}^{-1}$ terdeteksi puncak yang menunjukkan gugus $\mathrm{OH}$ dari komponen selulosa, pektin, hemiselulosa, dan lignin yang terkandung di dalam yeast. vibrasi peregangan gugus $\mathrm{OH}$ terjadi pada rentang panjang gelombang yang lebar sehingga mewakili keberadaan gugus hidroksil bebas dan ikatan $\mathrm{OH}$ dari asam karboksilat (Cheraghi et al., 2015). Pada area 2922,48 $\mathrm{cm}^{-1}$ terdeteksi puncak yang menunjukkan gugus $-\mathrm{CH}_{3}$. Pada area $1624,55 \mathrm{~cm}^{-1}$ terdeteksi puncak yang menunjukkan gugus karboksil $-\mathrm{C}=\mathrm{O}$. Pada area $1232,71 \mathrm{~cm}^{-1}$ dan $1019,09 \mathrm{~cm}^{-1}$ masingmasing terdeteksi puncak yang menunjukkan gugus $\mathrm{S}=\mathrm{O}$ dan $\mathrm{C}-\mathrm{N}$.

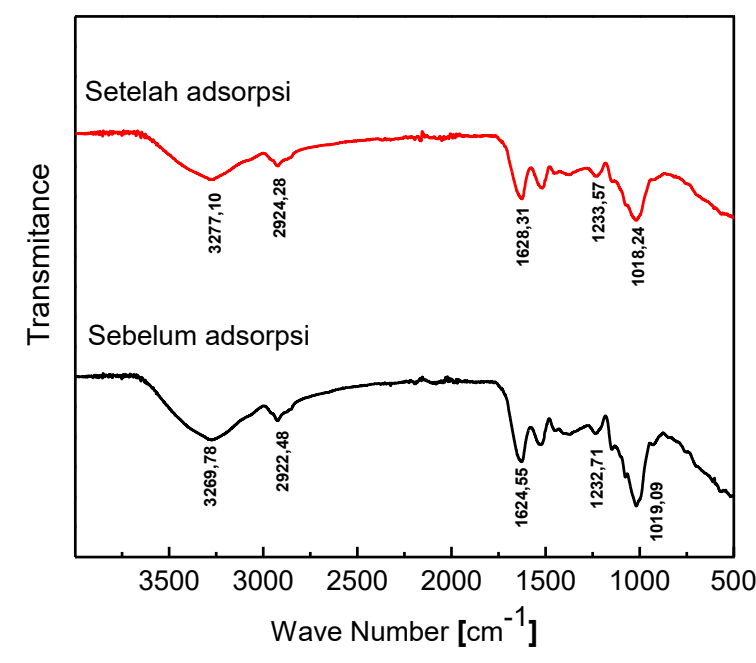

Gambar 4. Spektra FT-IR Biosorben sebelum dan setelah adsorpsi logam $\mathrm{Cu}(\mathrm{II})$.
Proses biosorpsi logam $\mathrm{Cu}(\mathrm{II})$ menyebabkan terjadinya pergeseran dari puncak spectra FTIR. Hasil analisis FT-IR Saccharomyces cerevisiae setelah mengikat logam $\mathrm{Cu}(\mathrm{II})$ menunjukkan bahwa puncak gugus $\mathrm{OH}$ pada daerah $3269,78 \mathrm{~cm}^{-1}$ bergeser menjadi $3277,10 \mathrm{~cm}^{-1}$. Perubahan puncak adsorpsi $\mathrm{OH}$ tersebut menunjukkan bahwa gugus hidroksil telah berubah dari struktur multimer menjadi monopolimer. Pada area puncak yang lain terjadi pergeseran area puncak dari 2922,$48 ; 1624,55 ; 1232,71 ; 1019,09 \mathrm{~cm}^{-1}$ masing-masing menjadi 2924,28; 1628,31; 1233,57; 1018,24 $\mathrm{cm}^{-1}$. Perubahan area puncak tersebut tidak hanya mengindikasikan keterlibatan gugus fungsi dalam biosorpsi $\mathrm{Cu}$ (II) namun terdapat kemungkinan bahwa biosorpsi dapat terjadi melalui proses pertukaran ion logam di dalam larutan dipindahkan ke biomassa yang mengarah pada pembentukan ikatan kimia antara ion $\mathrm{Cu}$ (II) dengan gugus fungsi tersebut (Wu et al., 2012)

\section{Kesimpulan}

Limbah Saccharomyces cerevisiae dapat dimanfaatkan sebagai alternatif biosorben yang efektif dalam mengikat logam $\mathrm{Cu}(\mathrm{II})$. Hasil penelitian menunjukkan bahwa kemampuan biosorben dalam mengikat logam $\mathrm{Cu}$ (II) di dalam larutan dipengaruhi oleh $\mathrm{pH}$, waktu kontak, dan massa adsorben. Peningkatan $\mathrm{pH}$ larutan menyebabkan peningkatan persen removal $\mathrm{Cu}(\mathrm{II})$. Peningkatan massa biosorben di dalam larutan menyebabkan meningkatnya $\mathrm{Cu}$ (II) yang teradsorpsi sehingga mengarah pada peningkatan persen removal $\mathrm{Cu}(\mathrm{II})$. Namun, biosorpsi logam berat $\mathrm{Cu}$ mengalami penurunan seiring dengan meningkatnya waktu kontak antara biosorben dengan larutan $\mathrm{Cu}$. Persen removal $\mathrm{Cu}(\mathrm{II})$ mencapai nilai maksimal terjadi pada kondisi $\mathrm{pH} 5$ dengan massa biosorben 0,75 serta waktu kontak 1 jam yaitu sebesar 55,36\%. Hal tersebut dikarenakan $\mathrm{pH}$ memiliki pengaruh terhadap situs aktif dinding sel mikroorganisme dan spesiasi logam dalam larutan. Proses regenerasi biosorben dengan larutan $\mathrm{HNO}_{3} 0,1 \mathrm{M}$ menyebabkan penurunan massa biosorben sebesar $0,18 \mathrm{~g}$ serta kerusakan struktur biosorben sehingga biosorben mengalami penurunan kemampuan adsorpsi $\mathrm{Cu}(\mathrm{II})$ dari $55,36 \%$ menjadi $48,20 \%$.

\section{Daftar Pustaka}

Bhuvaneshwari, S., Velmurugan, S., S. Senthilrani, S. (2011). Biosorption of Chromium from Aqueous Waste Water using Chitosan and Desorption of 
Chromium from Biosorbent for Effective Reuse. Journal of Chemistry and Environment, 15 (2) 185-191.

Cheraghi, E., Ameri, E., Moheb, A. (2015). Adsorption of Cadmium lons from Aqueous Solutions Using Sesame as a Low-Cost Biosorbent: Kinetics and Equilibrium Studies. International Journal of Environmental Science and Technology, 12 (8) 2579-2592.

Duda-Chodak, A., Tarko, T., Milotta, K. (2012). Applicability of Different Kinds of Yeast Biomass to Lead Removal from Water. Journal of Elementology, 17 (1) 718.

Elystia, S., Putri, R.R., Muria, S.R. (2018). Biosorpsi Kromium (Cr) pada Limbah Cair Industri Elektroplating Menggunakan Biomassa Ragi Roti (Saccharomyces cerevisiae). Jurnal Dampak, 15 (1) 1-6.

Fadel, M., Hassanein, N.M., Elshafei, M.M., Mostafa, A.H., Ahmed, M.A., Khater, H.M. (2017). Biosorption of Manganese from Groundwater by Biomass of Saccharomyces Cerevisiae. Housing and Building National Research Center Journal, 13 (1) 106-113.

Ferraz, A.I., Tavares, T., Teixeira, J.A. (2004). Cr(III) Removal and Recovery from Saccharomyces Cerevisiae. Chemical Engineering Journal, 105 11-20.

Fitriyah, A.W., Utomo, Y., Kusumaningrum, I.K. (2013). Analisis Kandungan Tembaga (Cu) dalam Air dan Sedimen di Sungai Surabaya. Jurnal Kimia UNM, 2 (1) 1-8.

Gochev, V., Velkova, Z., Stoytcheva, M. (2014). Biosorption of Cooper (II) by Immobilized Dead Biomass of Saccharomyces Cerevisiae. Biotechnology \& Biotechnological Equipment, 24 (1) 607 612.

Irawan, C., Dahlan, B., Retno, N. (2015). Pengaruh Massa Adsorben, Lama Kontak dan Aktivasi Adsorben Menggunakan $\mathrm{HCl}$ terhadap Efektivitas Penurunan Logam Berat (Fe) dengan Menggunakan Abu Layang sebagai Adsorben. Jurnal Teknologi Terpadu, 3 (2) 107-116.

Khoirunnisa, A. dan Senam, S. (2017). Pengaruh Interferensi lon Kadmium $\left(\mathrm{Cd}^{2+}\right)$ Terhadap Biosorpsi Ion Timbal $\left(\mathrm{Pb}^{2+}\right)$ Oleh Sel Ragi Saccharomyces Cerevisiae. Jurnal Kimia Dasar, 6 (2) 53-58.
Kresnawaty, I., dan Panji, T. (2007). Biosorpsi Logam Zn oleh Biomassa Saccharomyces cerevisiae. Menara Perkebunan, 75 (2) 8092.

Maier, R.M., Pepper, I.L., Gerba, C.P. (2009). Environmental Microbiology $2^{\text {nd }}$ Edition (p.387). Elsevier inc.

Naimah, S. dan Ermawati, R. (2011). Biosorpsi Logam Berat $\mathrm{Cr}(\mathrm{VI})$ dari Limbah Industri Pelapisan Logam Menggunakan Biomassa Saccharomyces cerevisiae dari Hasil Samping Fermentasi Bir. Jurnal Kimia Kemasan, 33 (1) 113-117.

Peng, Q., Liu, Y., Zeng, G., Xu, W., Yang, C., Zhang, J. (2010). Biosorption of Copper(II) by Immobilizing Saccharomyces cerevisiae on The Surface of Chitosan-Coated Magnetic Nanoparticles from Aqueous Solution. Journal of Hazardous Materials, 177 (1-3) 676-682.

Pratiwi, N.A., Sunarto, S. (2018). Perbandingan Validasi Metode Analisis Ion Tembaga(II) Tanpa Pengompleks dan Dengan Pengompleks NaDietilditiokarbamat Secara Spektrofotometri Uv-Vis. Jurnal Kimia Dasar, 7 (3) 96-105.

Saeed, A., dan lqbal, M. (2003). Bioremoval of Cadmium from Aqueous Solution by Black Gram Husk (Cicer arientinum). Journal of Water Research, 37 (14) 34723480.

Sembiring, Z., Buhani, B., Suharso, S., Sumadi, S. (2009). Isoterm Adsorpsi Ion $\mathrm{Pb}$ (II), Cu(II) dan Cd(II) Pada Biomassa Nannochloropsis sp yang Dienkapsulasi Akuagel Silika. Indo. J. Chem, 9 (1) 1-5.

Setiawan, A., Afiuddin, A.E., Aini, Q., Dewi, T.A. (2018). Recovery Koagulan dari Sludge WWTP Pembangkit Listrik Tenaga Uap sebagai Alternatif Pengolahan Air Limbah secara Kimia. Jurnal Riset Teknologi Industri, 12 (2) 126-138.

Wu, Y., Wen, Y., Zhou, J., Dai, Q., Wu, Y. (2012). The Characteristics of Waste Saccharomyces cerevisiae Biosorption of Arsenic (III). Environmental Science and Pollution Research, 19 (8) 3371-3379. 